\title{
Deskripsi Indikator Program Keluarga Berencana di Provinsi Kalimantan Utara
}

\author{
${ }^{1}$ M. Rasyid Ridha, ${ }^{2}$ Edwardus I. Goma* \\ ${ }^{1}$ Perwakilan BKKBN Provinsi Kalimantan Timur \\ 2 Pendidikan Geografi Universitas Mulawarman \\ Korespondensi: *edwardus@fkip.unmul.ac.id
}

\begin{abstract}
Abstrak
Permasalahan jumlah dan komposisi penduduk menjadi masalah utama di bidang kependudukan bagi sebagian besar negara berkembang. Dalam beberapa dekade terakhir sejak era tahun 1980-an negara-negara berkembang dan tertinggal mulai menyadari pentingnya mengurangi tingkat pertumbuhan penduduk. The International Conference on Population and Development Program of Action (ICPD) 1994 secara eksplisit menjadikan target program demografi dan keluarga berencana untuk mendukung kebijakan secara luas yang mencakup kebijakan reproduksi termasuk didalamnya program keluarga berencana. Hasil sensus penduduk tahun 2010 menunjukkan kenaikan laju pertumbuhan penduduk Indonesia dari 1,45 persen pada periode 1990-2000 menjadi 1,49 persen pada periode 2000-2010. Kalimantan Utara merupakan provinsi pemekaran yang terbentuk tahun 2011 baru menjadi pembahasan dalam SDKI secara terpisah dari Provinsi Kalimantan Timur pada tahun 2017. Tulisan ini bertujuan untuk memberikan menggambarkan kondisi capaian program Keluarga Berencana di Provinsi Kalimantan Utara berdasarkan beberapa indikator TFR, CPR, Modern CPR, MKJP, Unmeet Need dan Pengetahuan Akseptor Keluarga Berencana dibandingkan dengan capaian Provinsi lainnya di wilayah Regional Kalimantan dan Nasional. Data yang digunakan dalam penelitian ini adalah data sekunder hasil SDKI 2017 dengan menggunakan analisis deskriptif. Indikator - indikator program Keluarga Berencana disajikan dan dianaliss dalam bentuk grafik. Hasil Survei Demografi dan Kesehatan Indonesia (SDKI) 2017 menunjukkan capaian Provinsi Kalimantan Utara untuk indikator TFR 2,8; CPR 52,8; Modern CPR 46.9; MKJP 8,5; Unmeet Need 15,8. Hampir di semua indikator yang digunakan untuk mengukur program keluarga berencana provinsi Kalimantan Utara mendapatkan nilai di bawah provinsi-provinsi lainnya yang berada di regional Kalimantan dan juga nasional.

Kata Kunci: Keluarga Berencana, Indikator, Kalimantan Utara
\end{abstract}

\section{Description of Family Planning Program Indicators in North Kalimantan Province}

\begin{abstract}
The problem of population size and composition is the main problem in the population sector for most developing countries. In the last few decades since the 1980s developing and underdeveloped countries have begun to realize the importance of reducing their population growth rates. The International Conference on Population and Development Program of Action (ICPD) in 1994 explicitly targeted demography and family planning programs to support broad policies covering

Deskripsi Indikator Program Keluarga Berencana ...

M. Rasyid Ridha, Edwardus I. Goma


reproductive policies, including family planning programs. The results of the 2010 population census have shown an increase in Indonesia's population growth rate from 1.45 percent in the 1990-2000 period to 1.49 percent in the 2000-2010 period. North Kalimantan is a new province that was formed in 2011 and has only been discussed in the IDHS separately from East Kalimantan Province in 2017. This paper aims to describe the condition of the achievements of the Family Planning program in North Kalimantan Province based on several indicators of TFR, CPR, Modern $C P R$, long-term contraceptive methods, Unmeet Need and Knowledge of Family Planning Acceptors compared to the achievements of other Provinces in the Kalimantan Regional and National regions. The data used in this research is secondary data from the 2017 IDHS results with descriptive analysis. Family planning program indicators are presented and analyzed in graphical form. The results of the 2017 Indonesian Demographic and Health Survey (IDHS) show the achievements of North Kalimantan Province for the TFR indicator 2.8, CPR 52.8, Modern CPR 46.9, LTCM 8.5, Unmeet Need 15.8. Almost all the indicators used to measure the family planning program, the province of North Kalimantan scored below other provinces in the Kalimantan region as well as nationally.

Keywords: family planning, Indicators, North Kalimantan

\section{Pendahuluan}

Permasalahan kependudukan telah menjadi kajian utama berbagai negara di dunia. Setiap negara berusaha untuk membangun sumber daya manusia yang dimiliki dalam mencapai stabilitas politik, ekonomi, sosial, maupun budaya sehingga tercipta rakyat yang sejahtera. Masalah kependudukan bukanlah sekedar masalah jumlah, tetapi juga menyangkut masalah kepentingan pembangunan dan kesejahteraan masyarakat. Jumlah penduduk yang besar, tingkat pertumbuhan penduduk yang masih tinggi, serta penyebaran penduduk antar daerah yang kurang seimbang merupakan ciri kondisi kependudukan di sebagian besar negara berkembang. Kondisi kependudukan tersebut sangat mempengaruhi jumlah dan komposisi penduduk sehingga menjadi masalah utama di bidang kependudukan.

Beberapa dekade terakhir sejak era tahun 1980-an, negara-negara berkembang dan tertinggal mulai menyadari pentingnya mengurangi tingkat pertumbuhan penduduk. The International Conference on Population and Development Program of Action (ICPD) tahun 1994 secara eksplisit menjadikan target program demografi dan keluarga berencana untuk mendukung kebijakan secara luas yag mencakup kebijakan reproduksi termasuk didalamnya program keluarga berencana, (UNFPA, 2004). Sebanyak 179 negara ikut serta dalam Program Aksi ICPD tahun 1994 yang ditetapkan untuk menyediakan akses secara menyeluruh terhadap program keluarga berencana dan pelayanan kesehatan Deskripsi Indikator Program Keluarga Berencana ... M. Rasyid Ridha, Edwardus I. Goma 
seksual dan hak-hak reproduksi. Delegasi negara peserta ICPD tahun 1994 mencapai kesepakatan bahwa kesetaraan dan pemberdayaan perempuan merupakan prioritas global. Variabel fertilitas dan kematian yang didalamnya termasuk masalah kesehatan, KB, dan pertumbuhan penduduk, merupakan variabel utama yang berdampak langsung terhadap kesejahteraan masyarakat suatu negara. Namun, pembahasan mengenai kebijakan kependudukan di berbagai negara masih menjadikan fertilitas sebagai permasalahan utama.

Pemerintah Indonesia memandang pertumbuhan penduduk Indonesia sangat tinggi sehingga menjadi salah satu permasalahan utama (United Nation, 2013). Kebijakan kependudukan (Population Policy) di Indonesia memang secara sempit diartikan sebagai pengendalian fertilitas (Fertility Control). Kebijakan kependudukan sesungguhnya tidak hanya pada permasalahan Fertility Controlyang di Indonesia dikenal dengan program Keluarga Berencana melainkan lebih luas dari itu (Beyond Family Planning). Disamping pengendalian tingkat kelahiran, kebijakan kependudukan juga termasuk kebijakan mobilitas penduduk dan kebijakan kesehatan yang pada akhirnya bertujuan untuk mengurangi tingkat kematian (mortalitas), khususnya kematian ibu dan anak.

Keluarga Berencana pertama kali ditetapkan sebagai program pemerintah Indonesia pada tanggal 29 Juni 1970, bersamaan dengan dibentuknya Badan Koordinasi Keluarga Berencana Nasional. Namun untuk program Keluarga berencana itu sendiri sudah mulai dilakukan sejak tahun 1957 (Goma, 2019). Kelembagaan program keluarga berencana di Indonesia dimulai ketika Presiden Soeharto menandatangani deklarasi pemimpin dunia tentang kependudukan pada tahun 1967, mendirikan lembaga keluarga berencana pada tahun 1968, dan menjadikan status lembaga keluarga berencana menjadi dewan koordinator yang bertanggung jawab langsung kepada presiden pada tahun 1970 sehingga program Keluarga berencana mempunyai kedudukan formal dan melembaga (Hull, 2007).

Jumlah penduduk yang besar, tingkat pertumbuhannya yang masih tinggi, dan penyebaran antar-daerah yang kurang seimbang merupakan merupakan masalah pokok di bidang kependudukan. Laju pertumbuhan penduduk yang tinggi berpengaruh terhadap pembangunan kualitas penduduk yang dapat dilihat pada angka Indeks Pembangunan Manusia yang masih tertinggal bila dibandingkan negara-negara lain. Penanganan terkait laju pertumbuhan yang tinggi yang tidak Deskripsi Indikator Program Keluarga Berencana ... 
diikuti dengan peningkatan kualitas penduduk yaitu dengan program keluarga berencana (Handayani, 2010). Program keluarga berencana nasional merupakan program yang diharapkan akan membantu keluarga termasuk individu anggota keluarga dalam kehidupan berkeluarga sehingga dapat tercipta sebuah keluarga berkualitas. Hasil sensus penduduk tahun 2010 menunjukkan kenaikan laju pertumbuhan penduduk Indonesia dari 1,45 persen pada periode 1990-2000 menjadi 1,49 persen pada periode 2000-2010 (BPS, 2011).

Beberapa indikator yang digunakan dalam mengukur keberlangsungan program KB adalah Angka Fertilitas Total (TFR), Tingkat Pemakaian Kontrasepsi (CPR), Kebutuhan ber-KB yang tidak terpenuhi (Unmeet Need) dan faktor faktor lainnya (UNFPA, 2017). Provinsi Kalimantan Utara merupakan yang baru terbentuk pada tahun 2011 dan pada pelaksanaan SDKI tahun 2012 masih bergabung dengan Provinsi Kalimantan Timur. Merupakan hal yang menarik untuk melihat bagaimana capaian program keluarga berencana di provinsi paling muda dalam hal capaian dan target Nasional, seperti untuk indikator CPR, Unmet Need dan indikator - indikator lainnya berdasarkan SDKI 2017. Tulisan ini bertujuan untuk menggambarkan kondisi capaian program Keluarga Berencana di Provinsi Kalimantan Utara berdasarkan beberapa indikator dibandingkan dengan capaian Provinsi lainnya di wilayah Kepualauan Kalimantan dan capaian program Keluarga Berencana secara Nasional.

\section{Metode}

Data yang digunakan dalam penelitian ini adalah data sekunder yang telah dikumpulkan dan dipublikasikan oleh orang, badan, instansi lembaga maupun telaah pustaka yang berkaitan dengan tema penelitian. SDKI 2017 menyediakan gambaran menyeluruh tentang kondisi terkini mengenai kependudukan, keluarga berencana (KB), kesehatan reproduksi, dan kesehatan ibu dan anak di Indonesia. Tujuan utama SDKI 2017 adalah menyediakan estimasi terbaru indikator demografi dan kesehatan. Survei ini dilaksanakan di 34 (tiga puluh empat) provinsi di seluruh Indonesia, menghimpun informasi mengenai latar belakang sosial-ekonomi, fertilitas, kontrasepsi, kehamilan dan pemeriksaan sesudah melahirkan, imunisasi anak, kesehatan dan gizi anak, perkawinan dan kegiatan sosial, preferensi fertilitas, HIVAIDS, dan isu kesehatan lainnya (BKKBN, 2018).

Deskripsi Indikator Program Keluarga Berencana ...

M. Rasyid Ridha, Edwardus I. Goma 
Data sekunder dalam penelitian ini merupakan hasil Survei Demografi dan Kesehatan Indonesia (SDKI) tahun 2017 tentang beberapa indikator Keluarga Berencana, seperti Total Fertility Rate (TFR), Contraceptive Prevalence Rate (CPR), Jenis Kontrasepsi, dan Unmet Need (UN). Analisis yang digunakan adalah analisis deskriptif terhadap Indikator - indikator program Keluarga Berencana. Hasil analisis disajikan dalam bentuk grafik sehingga bisa memberikan gambaran hasil survei. Penelitian ini hanya sebatas medeskripsikan beberapa indikator Keluarga Berencana di Provinsi Kalimantan Utara dibandingkan dengan provinsi lain di wilayah Kalimantan dan Nasional.

\section{Hasil dan Pembahasan}

\section{Total Fertility Rate}

Total Fertility Rate atau angka kelahiran total merupakan salah satu indikator untuk mengukur capaian program KB. Angka kelahiran total secara sederhana diartikan sebagai jumlah total anak yang lahir dari seorang wanita selama masa usia subur. Idealnya CPR dan TFR memiliki hubungan terbalik, artinya semakin tinggi pasangan usia subur yang menjadi peserta KB aktif maka angka kelahiran total (TFR) akan semakin rendah. Indonesia menargetkan tingkat TFR berada di angka 2,28 pada RPJMN 2015 - 2019, sedangkan UN menargetkan TFR sebesar 2,2 pada tahun 2050 sehingga replacement level fertility secara global belum tercapai hingga 2050 (UN 2019).

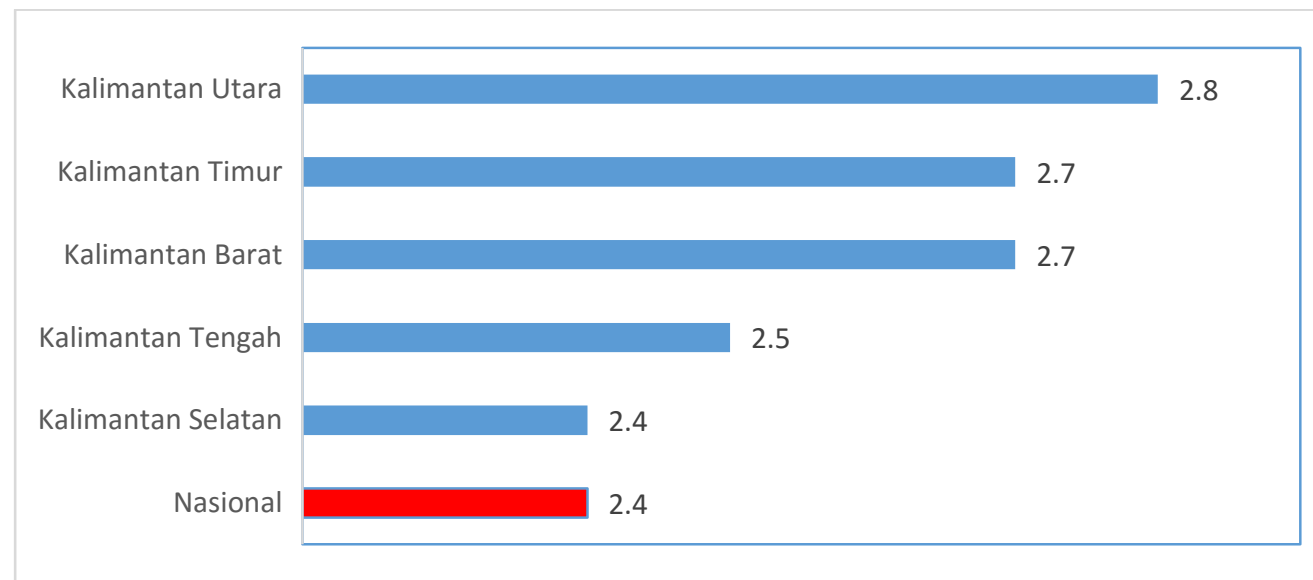

Gambar 1. Angka Kelahiran Total/Total Fertility Rate (TFR) Provinsi

Regional Kalimantan dan Nasional, SDKI 2017

Deskripsi Indikator Program Keluarga Berencana ... 
Data SDKI tahun 2017 menunjukkan bahwa secara nasional TFR sebesar 2,4; nilai ini mengalami penurunan 0,2 dibandingkan nilai TFR hasil SDKI 2012 sebesar 2,6. Meskipun secara nasional mengalami penurunan, akan tetapi semua provinsi yang berada di regional Kalimantan masih mempunyai nilai TFR di atas rata-rata Nasional. Provinsi Kalimantan Utara menjadi Provinsi dengan nilai TFR tertinggi di region Kalimantan dengan nilai TFR 2,8. Nilai 2,8 mempunyai arti bahwa setiap perempuan di Provinsi Kalimantan Utara akan memiliki dua atau tiga orang anak sampai pada masa akhir kesuburannya.

\section{Contraceptive Prevalency Rate (CPR)}

Program aksi ICPD 1994 mencakup komitmen yang sangat jelas untuk memastikan bahwasanya setiap penduduk baik itu wanita dan laki-laki memiliki akses yang mudah dan berkualitas terhadap metode alat kontrasepsi yang aman dan efektif menurut usia, paritas, preferensi jumlah anggota keluarga dan faktor lainnya (UN, 1995). CPR merupakan proporsi wanita atau pasangannya yang sedang menggunakan paling tidak salah satu metode kontrasepsi, biasanya dilaporkan sebagai persentase wanita yang sudah menikah atau sudah menikah pada usia reproduksi (UN, 2018). CPR menjelaskan seberapa besar peserta KB aktif yang menggunakan paling tidak salah satu alat kontrasepsi

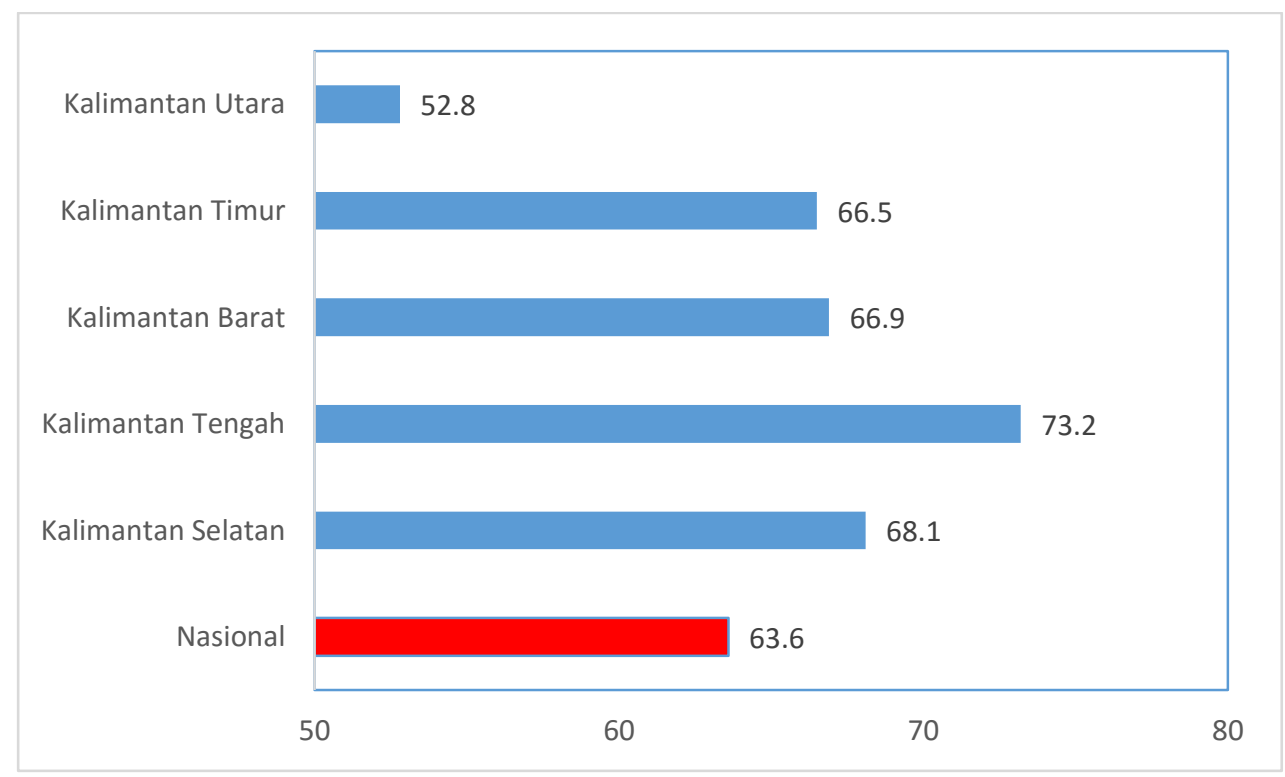

Gambar 2. Angka Contraceptive Pevalency Rate (CPR) Provinsi Regional Kalimantan dan Nasional, SDKI 2017 
Berdasarkan data SDKI tahun 2017 CPR secara nasional sebesar 63,6 persen meningkat selama 5 tahun sebesar 1,7 dari 61,9 persen pada SDKI 2012. Apabila CPR Nasional dibandingkan dengan CPR provinsi region Kalimantan maka ditemukan bahwa hampir semua provinsi berada di atas CPR Nasional kecuali Provinsi Kalimantan Utara yang berada di bawah level Nasional dengan nilai 52,8 persen.

\section{Modern CPR (mCPR)}

Beberapa metode kontrasepsi telah berkembang sejak lama misalnya kondom pria dan pantang berkala. Metode kontrasepsi PIL dan IUD mulai digunakan pada tahun 1960-an kemudian berkembang pula metode suntikan dan implan (UN, 2019). Metode kontrasepsi yang tersedia memiliki kelebihan dan kekurangan. Beberapa metode kontrasepsi dikembangkan untuk menjamin keberlangsungan penggunaan metode kontrasepsi menjadi sangat efektif bagi akseptor.

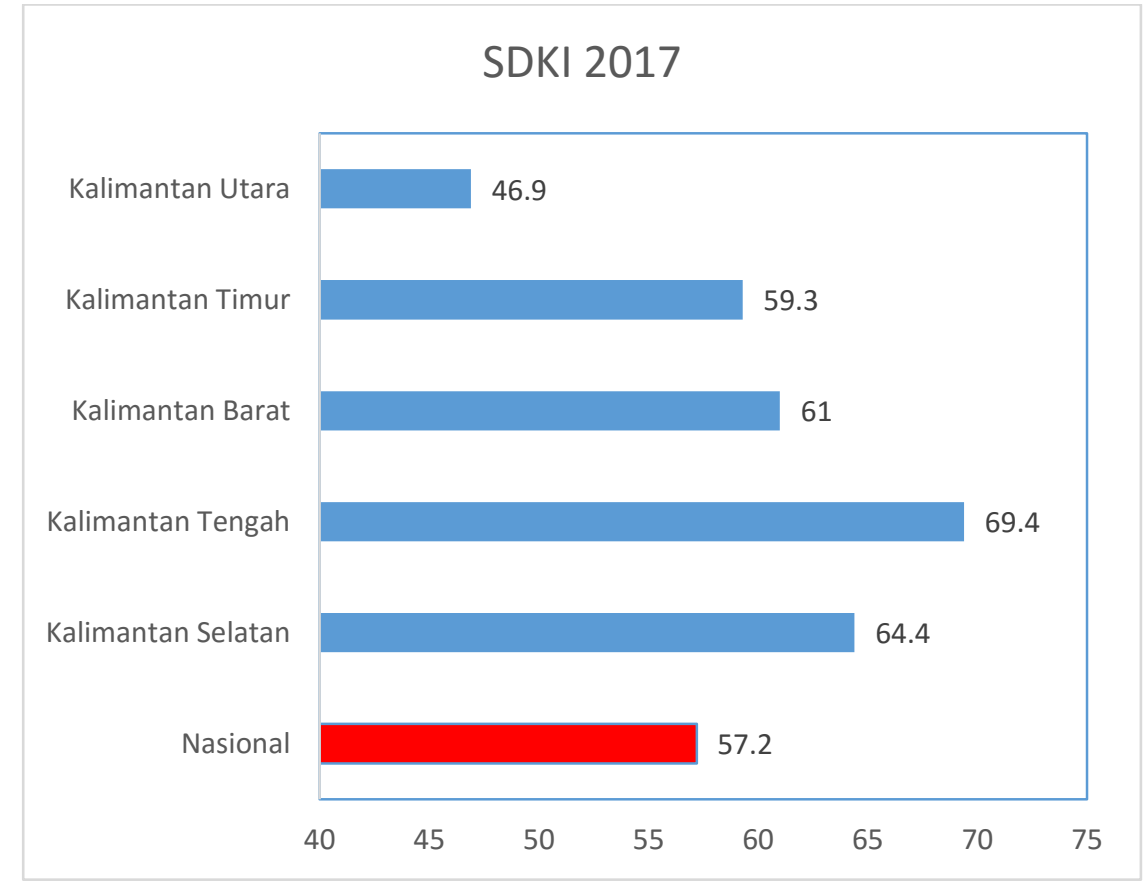

Gambar 3. Angka Modern Contraceptive Pevalency Rate (mCPR) Provinsi Regional Kalimantan dan Nasional, SDKI 2017

Kenaikan jumlah pengguna kontrasepsi (CPR) secara Nasional SDKI 2017 tidak dibarengi dengan kenaikan pengguna kontrasepsi modern. SDKI 2017 jumlah pengguna kontrasepsi modern mencapai 57,2 menurun dari 57,9 pada SDKI 2012. 
Secara region provinsi di region Kalimantan berada di atas level Nasional, kecuali provinsi Kalimantan Utara dengan 46,9.

\section{MKJP (Metode Kontrasepsi Jangka Panjang)}

Metode kontrasepsi jangka panjang merupakan salah satu metode kontrasepsi yang sangat efektif untuk mencegah dan menurunkan tingkat kelahiran. tindakan yang membantu individu atau pasangan usia subur yang sangat efektif untuk menghindari kelahiran, mengatur interval kelahiran, dan tidak mempengaruhi hubungan seksual (Hartanto, 2003). MKJP pemakaiannya dapat berfungsi minimal 3 tahun sampai seumur hidup. Jenis alat kontrasepsi ini yaitu IUD, MOP, MOW, dan Implan.

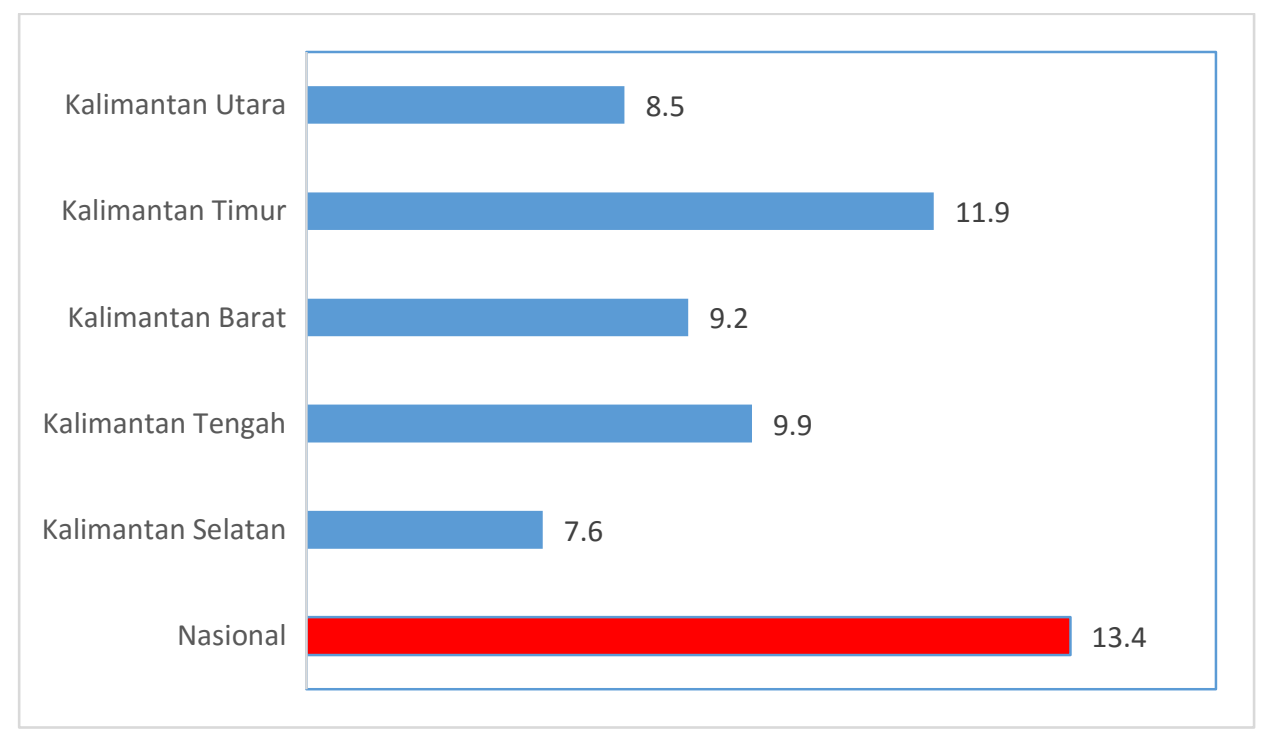

Gambar 4. Angka pengguna Metode Kontrasepsi Jangka Panjang (MKJP) Provinsi Regional Kalimantan dan Nasional, SDKI 2017

Data SDKI 2017 menunjukkan bahwa secara Nasional 13,4 persen Wanita Usia Subur yang menikah menggunakan salah satu metode kontrasepsi jangka panjang. Apabila dibandingkan dengan capaian provinsi region Kalimantan maka nilai disimpulkan bahwa semua provinsi region Kalimantan berada di bawah level Nasional dengan Provinsi Kalimantan Utara merupakan provinsi terendah penggunaan MKJP dengan 8,5 persen. 
Unmet Need (UN)

Salah satu indikator dalam pencapaian program keluarga berencana adalah terpenuhinya kebutuhan akseptor alat kontrasepsi. UN menunjukkan adanya kesenjangan antara keinginan reproduksi seorang wanita dengan perilaku yang berhubungan dengan kontrasepsi wanita tersebut. UN diartikan sebagai besarnya proporsi wanita yang ingin berhenti dan menunda kelahiran akan tidak menggunakan metode kontrasepsi apapun (UN, 2019). Semakin rendah nilai Unmeet Need maka semakin baik dalam mendukung peningkatan jumlah CPR.

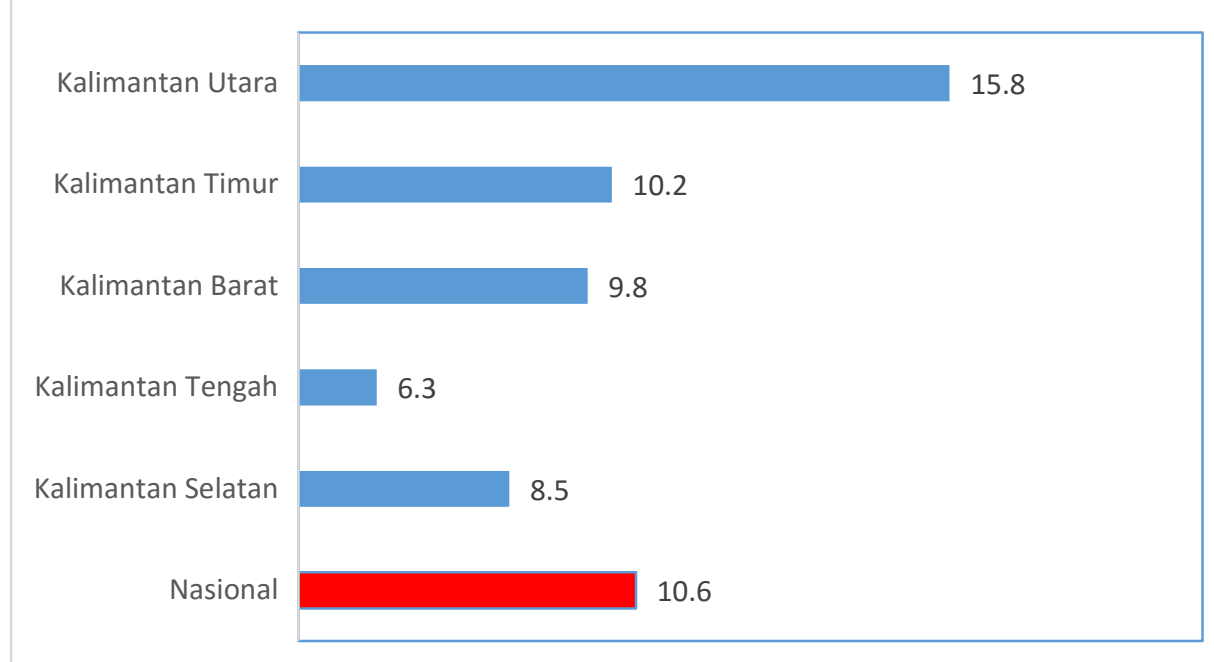

Gambar 5. Angka Unmeet Need Provinsi Regional Kalimantan dan Nasional, SDKI 2017

Secara nasional Unmeet Need Indonesia masih berada pada angka 10,6 berdasarkan data SDKI 2017 menurun 0,8 dari angka 11,4 pada SDKI 2012. Walaupun angkanya menurun akan tetapi nilai 10,6 masih cukup besar. Secara regional hampir semua provinsi di Kalimantan berada di bawah nilai Nasional kecuali Provinsi Kalimantan Utara $(15,8)$.

\section{Pengetahuan Akseptor Keluarga Berencana}

Salah satu faktor yang mempengaruhi tingkat penggunaan metode kontrasepsi oleh pasangan usia subur adalah pengetahuan tentang alat kontrasepsi yang berasal dari pemberian informasi dan konseling. Metode kontrasepsi termasuk di dalamnya alat maupun cara kontrasepsi modern dan tradisional. Metode kontrasepsi modern terdiri atas metode operasi wanita (MOW), metode operasi pria (MOP), Intra Uterine Divice (IUD), Implan, Pil, suntik, kondom, dan Metode Amenore Deskripsi Indikator Program Keluarga Berencana ... 
Laktasi (MAL). Metode Tradisional termasuk di dalamnya pantang berkala, senggama terputus, serta metode tradisional lainnya.

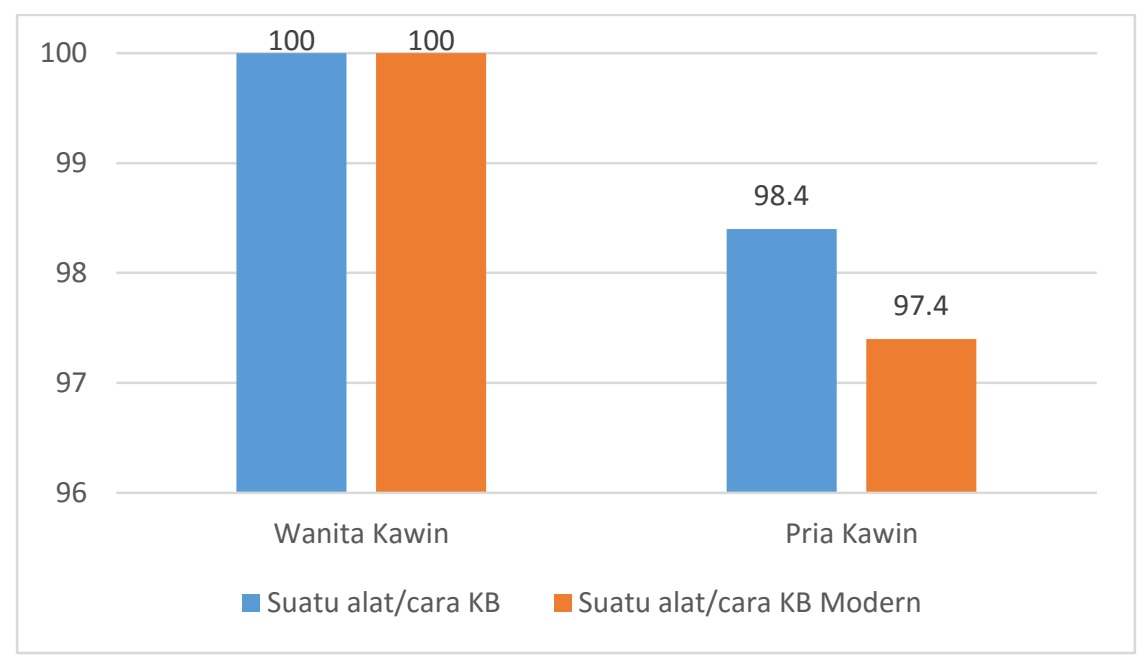

Gambar 6. Angka Pengetahuan Akseptor Keluarga Berencana Provinsi Kalimantan Utara, SDKI 2017

Berdasarkan SDKI 2017 untuk provinsi Kalimantan Utara, seluruh wanita kawin yang menjadi responden menyebutkan metode kontrasepsi yang dapat digunakan baik suatu alat/cara maupun alat/cara modern. Data menunjukkan pengetahuan pria kawin tentang metode kontrasepsi telah cukup tinggi, kecuali 1,6 persen yang tidak bisa menyebutkan suatu alat/cara kontrasepsi yang dapat digunakan untuk mencegah kehamilan.

\section{Kesimpulan}

Berdasarkan hasil penelitian terhadap data SDKI tahun 2017, maka ditarik kesimpulan sebagai berikut:

1. Secara nasional tingkat TFR mengalami penurunan, akan tetapi provinsi yang berada di regional Kalimantan masih mempunyai nilai TFR di atas rata-rata Nasional. Provinsi Kalimantan Utara menjadi Provinsi dengan nilai TFR tertinggi di region Kalimantan dengan nilai TFR 2,8.

2. Data SDKI tahun 2017 secara nasional menunjukkan angka CPR sebesar 63,6 persen meningkat selama 5 tahun sebesar 1,7 dari 61,9 persen pada SDKI 2012. Apabila CPR Nasional dibandingkan dengan CPR provinsi region Kalimantan maka ditemukan bahwa hampir semua provinsi berada di atas CPR Nasional 
kecuali Provinsi Kalimantan Utara yang berada di bawah level Nasional dengan nilai 52,8 persen.

3. Kenaikan jumlah pengguna kontrasepsi (CPR) secara Nasional SDKI 2017 tidak dibarengi dengan kenaikan pengguna kontrasepsi modern. SDKI 2017 jumlah pengguna kontrasepsi modern mencapai 57,2 menurun dari 57,9 pada SDKI 2012. Secara region provinsi di region Kalimantan berada di atas level Nasional, kecuali provinsi Kalimantan Utara dengan 46,9.

4. Data SDKI menunjukkan bahwa secara Nasional 13,4 persen Wanita Usia Subur yang menikah menggunakan salah satu metode kontrasepsi jangka panjang. Apabila dibandingkan dengan capaian provinsi region Kalimantan maka nilai disimpulkan bahwa semua provinsi region Kalimantan berada di bawah level Nasional dengan Provinsi Kalimantan Utara merupakan provinsi terendah penggunaan MKJP.

5. Unmeet Need Indonesia masih berada pada angka 10,6 berdasarkan data SDKI 2017 menurun 0,8 dari angka 11,4 pada SDKI 2012. Walaupun angkanya menurun akan tetapi nilai 10,6 masih cukup besar. Secara regional hampir semua provinsi di Kalimantan berada di bawah nilai Nasional kecuali Provinsi Kalimantan Utara di angka 15,8

6. Seluruh wanita kawin di Provinsi Kalimantan Utara bisa menyebutkan metode kontrasepsi yang dapat digunakan baik suatu alat/cara maupun alat/cara modern. Data menunjukkan pengetahuan pria kawin tentang metode kontrasepsi telah cukup tinggi, kecuali 1,6 persen yang tidak bisa menyebutkan suatu alat/cara kontrasepsi yang dapat digunakan untuk mencegah kehamilan.

\section{Daftar Pustaka}

Badan Kependudukan dan Keluarga Berencana Nasional (2018). Survei Demografi dan Kesehatan Indonesia 2017. BKKBN: Jakarta.

Badan Pusat Statistik. 2011. Pertumbuhan dan Persebaran Penduduk di Indonesia Hasil Sensus Penduduk 2010.https://sp2010.bps.go.id/files/ebook/pertumbuh an\%20dan\%20persebaran\%20penduduk\%20indonesia/index.html. September 2020.

Goma, Edwardus Iwantri. (2020). "Situasi Keluarga Berencana di Provinsi Kalimantan Timur" Georafflesia Vol. 4, No.2

Handayani, Sri. 2010. Buku Ajar Pelayanan Keluarga Berencana. Yogyakarta: Pustaka Rihama.

Deskripsi Indikator Program Keluarga Berencana ...

M. Rasyid Ridha, Edwardus I. Goma 
Hartanto, H. 2007, Keluarga Berencana dan Kotrasepsi, Pustaka Sinar Harapan: Jakarta

Hull, Terence H. 2007. The Global Family Planning Revolution: Three Decades ofPopulation Policies and Programs. The International Bank for Reconstruction and Development/ The World Bank: Washington, DC.

United Nations Population Fund. 2004. Programme of Action Adopted at the International Conference on Population and Development, Cairo. UNFPA: New York.

United Nations Population Fund. 2017. A Rights-Based Strategy for Accelerating Access to Integrated Family Planning and Reproductive Health Services to Achieve Indonesia's Development Goals. https://indonesia.unfpa.org/id/node/11884. 02 September 2020.

United Nations: Departement of Economic and Social Affairs. 2013. World Population policies 2013. UN: New York.

United Nations: Department of Economic and Social Affairs, 2018. https://www.un.org/en/development/desa/population/publications/dataset/cont raception/wcu2018/UNPD_WCU2018_Methodology.pdf. 02 September 2020

United Nations: Departement of Economic and Social Affairs. 2019. Contraceptive Use by Method 2019. UN: New York.

United Nations: Departement of Economic and Social Affairs. 2019. World Population Prospects 2019. UN: New York.

United Nations. 1995. Report of the International Conference on Population and Development. United Nations Publication: New York

Deskripsi Indikator Program Keluarga Berencana ...

M. Rasyid Ridha, Edwardus I. Goma 